\title{
Quality of Education in Independent and Franchise Private Secondary Schools in Pakistan
}

\author{
Munawar S. Mirza* \\ Nazia Manzoor ${ }^{* *}$
}

\begin{abstract}
Pakistan has a variety of privately managed schools. Inspired by the corporate model the large school systems offer franchise to the small schools in the name of better quality education leading to better market acceptability. This study was conducted to find out the difference in the quality of education provided by the franchise and independent private secondary schools. Ten schools of a renowned large spread school system were selected conveniently and ten independent schools were selected from the same localities for ensuring similarity of the context. Quality of education was define dalong input, process and product/output indicators. Opinion of Head Teachers (HTs)/ School principals was gathered through a questionnaire consisting five point rating scale on input and process indicators. Opinion of HTs about input indicators was validated through direct observation of the input indicators in the schools by one of the researchers. Students' achievement scores in the matriculation examination conducted by the Board of Intermediate and Secondary Education, Lahore were the indicator of quality output. The HTs of the two types of schools perceived no significant difference in the quality of input and process at their schools but the independent schools scoring slightly better on each of the two indicators. However, the independent private schools were significantly superior to the franchise schools in quality of output in terms of students' pass percentage and distribution over grades. Thus, the claim of franchising for better quality education was not supported by this research.
\end{abstract}

Keywords: secondary school, franchise private schools, independent private schools, quality of education, input, process and product indicators.

\footnotetext{
*Academic Advisor Virtual University of Pakistan, Email: drmsmirza1968@gmail.com

** MPhil Student of Lahore Leads University, Lahore
} 


\section{Introduction}

Secondary school education is an important step in the educational ladder as it is the terminal stage for many and a bridge between the elementary and higher education for those who continue their studies. The quality of higher education relies upon the quality of secondary level education. It is also viewed as imperative stage for national economic productivity (Govt. of Pakistan, 1959; Government of Pakistan1998; Imran, 2008). In Pakistan secondary education consists of four grades, 9th and 10th as secondary, and 11th and 12th as higher secondary education.

As per the Article 25A of the Constitution of Pakistan it is responsibility of the state to provide free universal education for children of ages 5-16 years. But, the number of public sector secondary schools in the country is only 12567 through which 2.189 million students of ages 13-16 are enrolled in grades 9-10 making a net enrolment of $20.16 \%$ of the relevant age group (Government of Pakistan, 2016). Due to similar figures in the past the government realized that its purse is too small to open the doors of education for all. Therefore, it encouraged the private sector to shoulder the burden of education. In response, the private sector has been growing since the New Education Policy 1979 (Government of Pakistan) that allowed the private sector to come back in education after nationalization of all educational institutions in 1972. The last two decades have seen unprecedented growth of the private educational institutions. Now, the number of private secondary schools in the country is 18668 constituting $61 \%$ of the total number of secondary schools. Enrollment in private schools is however, only 34\% of the total enrollment. Inclusive of the private sector the gross enrolment rate (GER) in grades $9-10$ is only $33 \%$ of the relevant age group (Government of Pakistan, 2016).

\section{Private Schools}

In Pakistan, 'Private School' is defined as the school not operated by the government. The word "Private" is used more in the USA and Canada to classify such schools, though they are also called "non-public" or "independent schools" (Gul \& Mehrunnisa, 2008).A 'Private School' is self-sufficient and self-governing in its finances and governance; it is neither reliant on national or local government for financing its operations, nor dependent on tax payer contributions; instead it is financed by tuition charges. The additional financing may come from one or more other sources such as donations, grant-in-aid and investment yield of an endowment. 
Pakistan inherited a long history of private provision in education and private sector had been a major provider of school education. In 1966 the percentages of students enrolled in private high and middle schools were 67.7 and 30.7, respectively. However, primary education was mostly provided by the government with the private sector enrolling only $8.8 \%$ of the total students (Zaki \& Khan, 1970). Under the National Education Policy 1972 all private institutions were nationalized. But, the subsequent National Education Policies 1979, 1992 and 1998-2010 made due provisions for the involvement of private sector in the educational development in the country (Ali, Ali \& Ghani, 2010).

\section{Franchise System}

The word 'franchise' originates from an old French word meaning 'privilege or freedom'. At present, the term 'franchise' refers to a right or privilege granted by a sovereign, a government, an organization, business or individual. As a concept, the history of franchising dates far back into the times when the kings used to grant certain commercial prerogative to individuals. William the Conqueror mostly used the system effectively in his agricultural policies, the royalties being men and materials required to sustain his army (Explore Ville School, 2012).

The business format franchising surfaced in the 1950s with the franchising of motels and fast food outlets. Franchiser not only allocates to the franchisee the right to use the franchisor's trademark or trade name and market its products and/or services but it also transfers to the franchisee all the operating systems, training programs, advertising programs and essentially all pertinent information that may help the franchisee flourish and succeed. In short, franchising conjoins all the expertise and the resources of a seasoned company to combine them with the driving aspiration and perseverance of an individual investor (Explore Ville School, 2012; Chow \& Frazer, 2003).A franchise takes its form through an accord or license between two legally independent parties which gives: a person or a group of people (franchisee) the right to market a product or services using the trademark or trade name of another business (franchisor); the right to market a product or service applying the operating modes of the franchisor. The franchisee has the obligation to pay the franchisor fees for these rights; and the franchisor has to provide rights and support to franchisee (Beshel, 2010; Chow \& Frazer, 2003). The franchisees have to operate their businesses according to the procedures and restrictions laid down by the franchisor in the franchisee agreement (Barbara, 2010). 


\section{Franchise System in Education}

Education franchising is a comparatively new phenomenon (Frazer \& Weaven, 2004). It offers advantages in terms of curriculum, advertising, latest\& modern teaching methodologies, management, quality control systems and trainings. A number of education franchises have emerged up worldwide, including Kumon Math \& Reading Centres (specializing in meticulous advancement in children's academic education), Sylvan Learning Centre (reading and math), American Learning (using their "Reading Game" to advance children's reading and math) and Language Odyssey which functions after-school programs that teach foreign language (Gubernick \& Burger, 1997). These examples describe only a small segment of education franchises now operating internationally; there are other franchises in Australia and New Zealand (Heaney \& Frazer, 2005).

Franchising in education has developed rapidly in Pakistan during the last two decades. The extensive rise of franchise-based educational networks in Pakistan shows that education is gainfuly pro-profit business. Many schools systems have launched their franchise networks. 'The Educators School System' is the pioneer of franchisebased education in Pakistan having 700 campuses in 212 cities. The Allied School system entered afterwards but has become the largest franchise chain with 730 campuses across 243 cities. There are atleast twenty more franchise chains including Dar-e-Arqam, Spirit Schools, Knowledge Schools, Smart Schools and many more (Perrigot \& Warraich, 2016) and BR Research, (2013).

Private schools including the franchise schools vary in quality and student fee. Even the elite school systems have coined franchise schools for the middle and low income groups. The 'Educator' is a brand of the Beaconhouse for the middle income people. Similarly, the Punjab Group has at least three types of franchise schools i.e. the Resource Academia for the elite, Allied Schools for the middle income group and the Education for All (EFA) for the low income group.

\section{Quality of Education in Franchise and Independent Private Schools}

The scale of school operations and quality of education is one of the hottest debates in education policy reform discussions all over the world (Elacqua, Contreras, \& Salazar, 2007). One argument is that larger schooling operations put forward education services more efficiently 
than small independent schools and that increasing the size of school operations lowers per-pupil costs to divert resources for improving the school and classroom facilities (Chubb, 2001). They further argue that larger schooling operations have more opportunities to access private investments and loans to spread out than the schools operated at smaller scale (Whittle, 2000; Symonds, 2000). McMeek in, 2003) asserted that being part of a franchise provides a sharing understanding within the network and facilitates the flow of information such as research on best practices, to the network members. School franchises accrue political benefits, credibility and legitimacy before the community. It is also assumed that by introducing competition and a business approach to schooling, franchise school system yield education outcomes more efficiently and proficiently than small independent schools (Chubb, 2001).

On the other hand the supporters of independent private schools believe that small independent private schools provide better quality education by creating intimate learning communities where students have closer relations with their teachers (Wasley et al., 2000) This approach minimizes the anonymity and seclusion and increases students' sense of belongingness (Barker \& Gump, 1964) creates advanced levels of cooperation among teachers, develops improved relations with school administrators and higher confidence in the school (Lee \& Loeb, 2000). In addition these schools support parents' involvement, which benefits students and the entire community (Schneider, Teske \& Marschall, 2000).

The research on the effectiveness of both types of schools is limited and has yielded mixed results. For instance research on Edison Schools of USA found that the performance of franchise schools fluctuates(Gill, Zimmer, Christman, \& Blanc, 2007).Similarly, the evaluations of independent private schools funded by the Gates Foundation concluded a broad variation in the quality of these schools (AIR \& SRI, 2005).

\section{Quality of Education}

Due to complex nature of teaching-learning process and involvement of a large number of stakeholders it is difficult to precisely define the 'quality' of education (Mirza, 2003; Dilshad, 2010).However, using the Stufflebeam's CIPP Model (Stufflebeam, 2003)the quality of education can be evaluated along four elements: context, input, process and output. Input indicators include quality of learners, excellence of faculty, quality of support services and physical infrastructure including building, 
classrooms, cafeteria, common rooms, library, computers, laboratories, play areas, incentives, transport, competences and experience of administrative staff (Zou \& Rasmussen, 2012). Other facilities include Information and communication technology (ICT), class size, teacher's salary (Bunting, 1997), teacher student ratio (Vos, 1996), hostel facility and financial support (Iqbal, 2004).

Process indicators can be described into six items: planning, delivery of curriculum, assessment and evaluation, accountability, research, development and other support services (Feldman, 1976; Vos, 1996). A number of other indicators have been mentioned by educationists such as students' dropout rate (Bunting, 1997), monitoring, management and teacher training, peer evaluation (Tam, 1999), co-curricular activities (Khan (2003) admission process, uniform procedure, quality control, quality assurance practices, supports facilities, teacher's proficiency to use audio visual aids, opportunities of professional development, content delivery methods (Iqbal, 2004), job security, discipline, campus climate, guidance and counseling (Ullah, 2005), recruitment process, research and development activities and remedial programs (Menon, Rama, Lakshmi, \& Bhat, 2007). UNICEF (2000) added to the process list the learner centred approaches and supervision. Dilshad and Iqbal (2010) added partnership with other institutions, learning resources, accreditation and documentation of information as process indicators. Zou, Du, \& Rasmussen (2012) included rules and regulations to this list.

Output indicators are achievement of learning outcomes, satisfaction of stakeholders, success of graduates in market (Bolaji \& Ali, 2013; Ullah, 2005).Tam (1999) considers values' acquisition (moral, ethical, social behaviour, attitude), satisfaction of stakeholders, cost effectiveness and student retentionas indicators of the quality output.

\section{Statement of the Problem}

The claims of the educational franchisers are high in Pakistan. Popularity and expansion of the private schools particularly the franchise schools indicate that public has accepted the stance of the franchisers of providing better quality education. Perrigot and Warraich (2016) conducted a qualitative study on the franchised schools and found that parents want to send their children to schools having a brand name which is accepted by the society and education community. But, there is hardly any empirical research on the comparative effectiveness of the two types of schools. 
This study compares the quality of education provided in franchise and independent middle level private secondary schools of Lahore along three elements of quality education that is input, process and product.

\section{Hypotheses}

The significance of difference between the two types of schools on the selected indicators was tested along the following null hypotheses at $\alpha=.05$.

$\mathrm{Ho}_{1}$ There is no significant association in the quality input for education and the types of private schools.

$\mathrm{Ho}_{2}$ There is no significant association in the quality of process of education and the types of private schools.

$\mathrm{Ho}_{3}$ There is no significant difference between the overall students' achievement scores in franchise and independent private schools.

$\mathrm{Ho}_{4}$ There is no association between the distribution of students' achievement grades and the type of schools.

Sub-hypotheses were also developed for indicators against each of the input and process elements as stated under section 'operational definition of variables'.

\section{Significance of the Study}

Both the franchise and independent private secondary schools claim to provide quality education. This study was conducted to compare the quality of education in these two types of secondary school of Lahore. The study might help policy makers in better planning while formulating strategies for managing the affairs of private schools. The study may also help in providing a base for comparison between various school types on essential parameters of quality education. It would render a feedback to the management of both sectors which may motivate them to strive for quality and become quality conscious, find out the deficient areas and to decide upon the strategies to improve the quality of education in their schools. As the study was conducted to compare different measures of quality improvement, so the findings and conclusions of the study might provide a benchmark for further research in this area.

\section{Population}

All franchise and independent private secondary schools of Lahore, their head teachers (HTs) and students of 10th grade constituted the population of the study. 


\section{Sample}

In the first step ten secondary schools out of one large franchise chain for the children of middle class were selected conveniently from Lahore city. Then the independent private schools were selected from the same vicinity in order to match their contextual features. The head teacher of each school was included in the sample.

\section{Operational Definitions of Variables}

Literature related to the concepts in the study was reviewed to identify different indicators of quality education. These quality indicators were divided into three categories: input, process and output.For this study following are the operational definitions of these quality indicators: Input indicators: Input indicators refer to:

Management: Management refers to management structure, operational manuals/rules \& regulations, schools prospectus, admission criteria, academic and activity calendar, all types of registers e.g. attendance register, stock register, complaint register and quality of administration staff in term of experience and qualification.

Teaching personnel: Teaching personnel refers to the number of teachers and support's staff, with their academic $\&$ professional qualification and teaching experience.

Infrastructure: The school infrastructure refers to proper buildings, library, computer labs, classrooms, playgrounds, laboratories for science experiments, water cooler \& filter and fencing and furniture, fixtures and fittings.

Process indicators: Process indicators include the following:

Content:

Content means appropriate and well-designed curriculum and effective learning materials such as supplementary reading material, workbooks and teacher guides etc.

Teaching learning process: Teaching Learning Process includes teaching methodologies, use of supplementary material and A.V Aids. 
Assessment and evaluation: Alignment of assessment with curriculum frameworks, assessment methods, assistance to teachers to make valid assessments, ensuring fair assessment, using technology to enhance assessment, provision of more informative reports to the stakeholders were the indicators included in assessment and evaluation.

Output indicators: Output comprises student's achievement as their scores obtained in 10th Grade Examination conducted by the Board of Intermediate and Secondary Education, Lahore.

\section{Research Instruments}

Questionnaire for head teachers of secondary schools:

This questionnaire consisted of input and process indicators of quality of education requiring answers on a five point Likert scale.

Observation checklist:

Observation checklist was developed to assess the status of schools on the first two indicators of the inputs that is, management and teaching personnel. The second status of the observation related to the infrastructure and physical facilities. Only those indicators were included in the check list that can be observed by an external visitor. The purpose to triangulate the information sought from the HTs. One of the researchers personally visited each school, checked the relevant material and data and recorded the observations.

Student examination scores in the matriculation examination of BISE, Lahore:

The examination results of students of grade 10 .

\section{Data Collection}

Formal consent and permission was taken from the concerned authorities of both the franchise and independent private secondary schools to conduct the study. The data were collected through personal visits to each sampled school. The questionnaire was administered to the HT in person with a response rate of $100 \%$. Observation of infrastructure and facilities were made and recorded. All the process of data collection took about three months. The achievement scores of secondary school students were obtained from each school. 


\section{Data Analysis}

To summarize different variables, descriptive statistics including frequencies, percentages, means, and standard deviations were used. Chisquare was used to test the hypotheses of association.

\section{Results}

\section{Input Indicators about Management and Teaching Personnel}

Twenty six indicators were included in the checklist. The data was recorded as available/not available. Independent schools scored slightly better than the franchise schools. Out of a maximum possible score of 260 the independent schools scored 208 and franchise schools scored205.

\section{Perception of HTs about Quality of Input Indicators}

HTs of both types of schools perceived the school's educational input as near excellent. The HTs of Independent schools had slightly better opinion about the inputs (Mean=3.82) as compared with the HTs of Franchise schools with a Mean=3.66. The difference in the perception of quality is however, was not statistically significant. The hypothesis (No.1) of no association between the type of school and the quality of inputs was thus accepted.

The HTs of Independent schools perceived the inputs better than those in the Franchise schools on seven of the thirteen indicators and equal on one indicator. Association between the school type and quality of inputs was significant only on one indicator, that is, quality of science laboratories perceived better in Independent schools. The sub hypothesis of association between school type and quality of science laboratories was rejected. 
Table 1

Quality of Educational Inputs Indicators in Franchise and Independent Secondary Schools as Perceived by their HTs

\begin{tabular}{|c|c|c|c|c|c|c|c|c|c|c|c|c|}
\hline \multicolumn{2}{|c|}{ Input Indicators } & School Type & $\begin{array}{r}0 \\
N A\end{array}$ & $\begin{array}{l}1 \\
P\end{array}$ & $\begin{array}{l}2 \\
F\end{array}$ & $\begin{array}{l}3 \\
S\end{array}$ & $\begin{array}{r}4 \\
V G\end{array}$ & 5 & Mean & \multicolumn{3}{|c|}{$X^{2}$} \\
\hline \multirow{2}{*}{1.} & \multirow{2}{*}{$\begin{array}{l}\text { Adequate Building } \\
\text { facility }\end{array}$} & Franchise & 0 & 0 & 1 & 2 & 3 & 4 & 4.00 & 1.05 & \multirow{2}{*}{3.73} & \multirow{2}{*}{0.29} \\
\hline & & Independent & 0 & 0 & 1 & 1 & 7 & 1 & 3.80 & 0.78 & & \\
\hline \multirow{2}{*}{2.} & Boundary & Franchise & 0 & 0 & 1 & 2 & 4 & 3 & 3.90 & 0.99 & \multirow{2}{*}{2.50} & \multirow{2}{*}{0.47} \\
\hline & wall for security & Independent & 0 & 0 & 1 & 0 & 4 & 5 & 4.30 & 0.94 & & \\
\hline \multirow{2}{*}{3.} & No. of fans in & Franchise & 0 & 0 & 0 & 2 & 4 & 4 & 4.20 & 0.78 & \multirow{2}{*}{0.44} & \multirow{2}{*}{0.80} \\
\hline & \&students & Independent & 0 & 0 & 0 & 1 & 5 & 4 & 4.30 & 0.64 & & \\
\hline \multirow{2}{*}{4.} & \multirow{2}{*}{$\begin{array}{l}\text { Qualityof } \\
\text { classfurniture }\end{array}$} & Franchise & 0 & 0 & 1 & 2 & 4 & 3 & 3.90 & 0.99 & \multirow{2}{*}{1.51} & \multirow{2}{*}{0.68} \\
\hline & & Independent & 0 & 0 & 0 & 3 & 5 & 2 & 3.90 & 0.73 & & \\
\hline \multirow{2}{*}{5.} & \multirow[t]{2}{*}{ Staff room } & Franchise & 0 & 0 & 1 & 2 & 4 & 3 & 3.90 & 0.99 & \multirow{2}{*}{3.00} & \multirow{2}{*}{0.55} \\
\hline & & Independent & 2 & 0 & 1 & 2 & 4 & 1 & 2.90 & 1.72 & & \\
\hline \multirow{2}{*}{6.} & Needed AV aids & Franchise & 1 & 1 & 1 & 1 & 5 & 1 & 3.10 & 1.59 & 56 & \\
\hline & available & Independent & 2 & 0 & 2 & 2 & 1 & 3 & 2.90 & 1.91 & 5.0 & 0. \\
\hline 7 & Science labs. & Franchise & 1 & 0 & 0 & 5 & 2 & 2 & 3.30 & 1.41 & 27 & \\
\hline 1. & well equipped & Independent & 0 & 0 & 0 & 3 & 7 & 0 & 3.70 & 0.48 & .21 & 0.03 \\
\hline & Comp. labswell- & Franchise & 2 & 0 & 0 & 2 & 4 & 2 & 3.20 & 1.81 & & \\
\hline 8. & $\begin{array}{l}\text { arranged \& } \\
\text { sufficientcomptrs }\end{array}$ & Independent & 0 & 0 & 1 & 2 & 4 & 3 & 3.90 & 0.99 & 3.20 & 0.52 \\
\hline 0 & Water filter & Franchise & 2 & 1 & 0 & 1 & 3 & 3 & 3.10 & 2.02 & 67 & \\
\hline 9. & available in school & Independent & 1 & 0 & 2 & 1 & 2 & 4 & 3.50 & 1.71 & .07 & 0.59 \\
\hline 10 & Sufficient & Franchise & 1 & 1 & 1 & 5 & 0 & 2 & 2.80 & 1.54 & 50 & 026 \\
\hline 10. & available in library & Independent & 0 & 0 & 1 & 3 & 4 & 2 & 3.70 & 0.94 & . .50 & 0.20 \\
\hline & Teacher & Franchise & 0 & 0 & 1 & 0 & 5 & 4 & 4.20 & 0.91 & & \\
\hline 11. & $\begin{array}{l}\text { Recruitment } \\
\text { procedure }\end{array}$ & Independent & 0 & 0 & 0 & 0 & 6 & 4 & 4.40 & 0.51 & 1.09 & 0.58 \\
\hline 1 & Admissions are & Franchise & 0 & 1 & 0 & 0 & 5 & 4 & 4.10 & 1.19 & 2 & 3 \\
\hline 12. & made on merit & Independent & 0 & 0 & 0 & 1 & 4 & 5 & 4.40 & 0.69 & .22 & J.J \\
\hline & Supp. materials & Franchise & 0 & 1 & 1 & 0 & 4 & 4 & 3.90 & 1.37 & & \\
\hline 13. & $\begin{array}{l}\text { with text books } \\
\text { available }\end{array}$ & Independent & 0 & 1 & 0 & 0 & 6 & 3 & 4.00 & 1.15 & 1.54 & 0.67 \\
\hline & & Franchise & 7 & 5 & 8 & 24 & 7 & 39 & 3.66 & 1.35 & & \\
\hline & & Independent & 5 & 1 & 9 & 19 & 9 & 37 & 3.82 & 1.17 & & \\
\hline
\end{tabular}

*NA: Not available $\quad$ P: Poor F: Fair $\quad$ S: Satisfactory VG: Very Good E: Excellent 


\section{Perception of Head Teachers about Quality of Process Indicators}

Independent schools were perceived slightly better by their HTs on process indicators of educational quality as compared with that perceived by the HTs of Franchise schools. The association between the school type and quality of process was statistically insignificant. H02 about equality of educational processes was thus accepted.

The Independent schools were rated better on eight of the thirteen indicators and equal on two while the Franchise schools got better rating on three indicators. Significant association between the school type and process was found only on one indicator that is, use of varied teaching methodologies used by the teachers. The sub hypothesis relating to use of similar teaching methodologies was rejected with the difference in favour of the Independent schools having teachers using a variety of teaching methods as compared with those in Franchise schools. 
Table 2

Quality of Educational Process Indicators in Franchise and Independent Secondary Schools According To School HTs

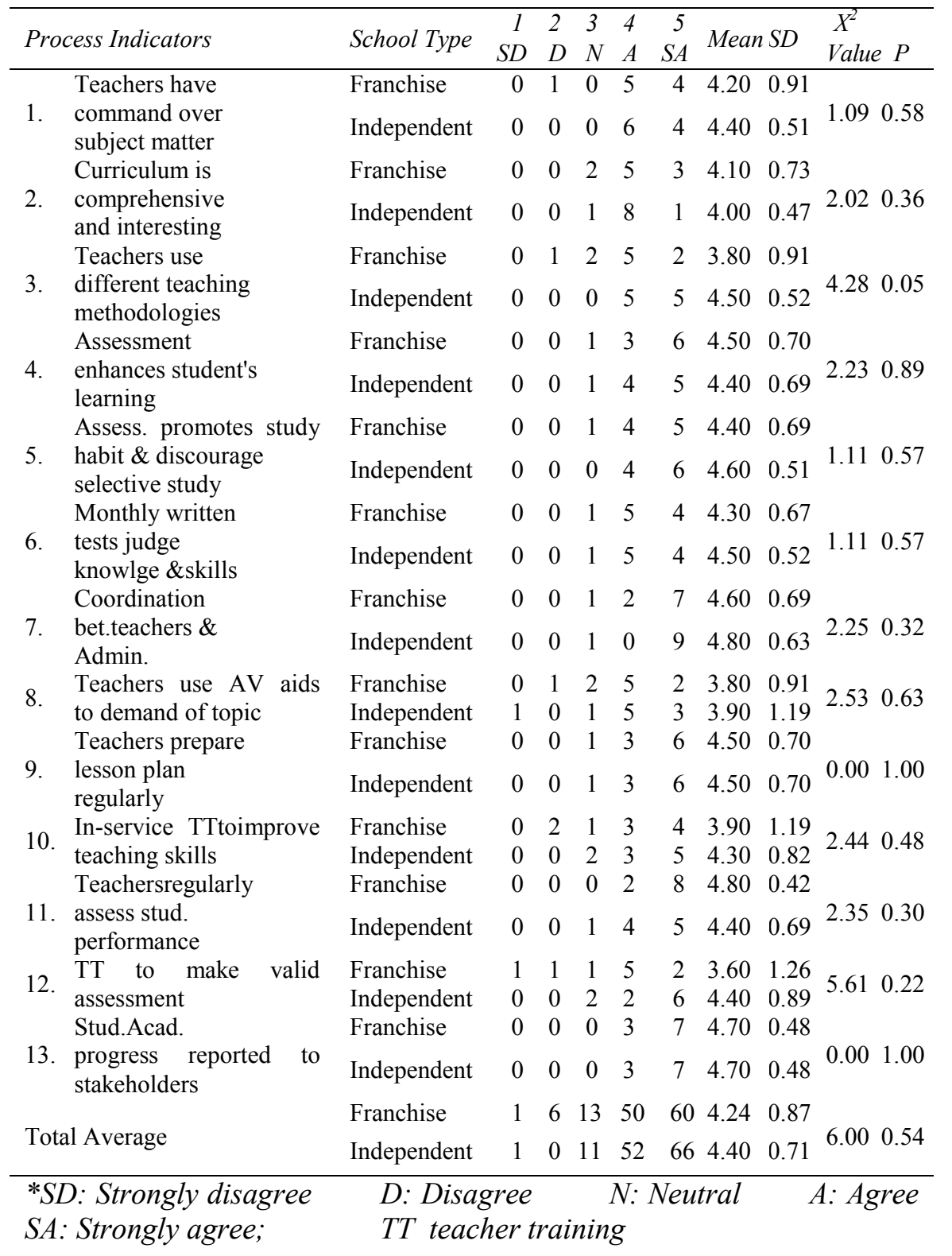


The observation data indicated that the HTs of both types of schools had somewhat overvalued the facilities and infrastructure of their schools. However, the researcher's observations supported the finding that independent schools had slightly better quality inputs as compared with those provided in the franchise schools.

\section{Students' Achievement}

Students' achievement was defined in the first stage as the percentage of students passing/ qualifying the matriculation examination and in the second stage as distribution of qualifying students in different grades.

The percentage of students qualifying the matriculation examination was higher in the Independent schools as compared with that in the Franchise schools though with a statistically insignificant margin. H03 about no difference between the type of school and student achievement was rejected in favour of independent schools.

Table 3

Pass Percentage of Students in the Independent and Franchise Schools in the Matriculation Examination

\begin{tabular}{llllll}
\hline School Type & Appeared & Passed & $\begin{array}{l}\text { Pass } \\
\text { Percentage }\end{array}$ & $Z$ & $P$ value \\
\hline Franchise & 373 & 303 & 81.23 & & \\
Independent & 449 & 374 & 83.29 & 0.77 & 0.44 \\
\hline
\end{tabular}

Quality of students' achievement was further analyzed by comparative placement of students of the two types of schools in different grades, i.e. A, B, C, D, etc. Again the students of Franchise schools had more positively skewed distribution as compared with that of students in the Independent schools indicating that more students of the Independent schools attained better grades than their counterparts in the Franchise schools. H04 of no association between the type of schools and quality of student achievement was rejected.

Table 4

Students Achievement of Franchise and Independent Private Secondary Schools

\begin{tabular}{llllllllll}
\hline School Type & & & & & & & & Chi & $P$ \\
& & $\mathrm{~A}+$ & $\mathrm{A}$ & $\mathrm{B}$ & $\mathrm{C}$ & $\mathrm{D}$ & $\mathrm{E}$ & Square & \\
\hline Franchise & $\mathrm{N}$ & 63 & 56 & 75 & 74 & 33 & 2 & & \\
& $\%$ & 16.89 & 15.01 & 20.10 & 19.83 & 8.84 & 0.53 & & \\
Independent & $\mathrm{N}$ & 81 & 86 & 98 & 84 & 31 & 0 & 12.0 & 0.36 \\
& $\%$ & 18.04 & 17.81 & 21.82 & 18.70 & 6.90 & 0.0 & & \\
\hline
\end{tabular}




\section{Discussion and Conclusion}

The sub-continent has a long history of privately managed educational institutions. The same was inherited by Pakistan. But, in 1972 all such educational institutions were nationalized. The private sector re-surged with a new commitment following the National Education Policy, 1979 but more rapidly during the last two decades. Motivated by the business model and the world trends the successful school entrepreneurs ventured upon franchising. The 'Educators' of the Beaconhouse school was the first franchising system launched in 2002. But, the largest franchise chain is the Allied Schools. The Franchising is based on the idea of selling its quality experience to the less experienced and individual entrepreneurs for better quality output by controlling, guiding and supporting on all aspects of quality input and processes. Studies comparing the effectiveness of different models of private schools are not available. For example Gill, Zimmer, Christman, \& Blanc (2007) reported fluctuation of quality among franchise schools and the evaluation of independent private schools funded by the Gates Foundation concluded a broad variation in the quality of these schools (AIR \& SRI, 2005). The present study compares the two types of schools i.e. the independent private schools and the franchise private schools. The results of the study do not support the claim of franchise system. Contrary to the claims it was found that Independent schools were slightly, though not significantly, better in terms of inputs and processes but were significantly superior to the franchise schools in quality of the output measured as pass percentage of students and their distribution over academic grades. The interest and proximity of the owners of the schools to their management and functioning is exactly similar in the two types of schools. The academic and professional qualifications of the HTs were also similar. It can be speculated that the franchisee might have a relaxed attitude because of using a brand name with an established trust and credibility for the stakeholders in the community. This might result in the neglect of facilities and processes by the owners to make a bigger profit margin. But, the independent private schools have to work harder to establish their name and credibility and social capital. Another possible reason might be the over trust by the franchisee in the services provided by the franchiser whereas in reality the franchiser is not fulfilling its obligations merely by neglect or due to lack of capacity and expertise to do so.

The issue under study is of high importance as many pro-profit large franchise school systems are evolving in the private and private public 
partnership (PPP) school modes. The concept of large school systems particularly the franchising should not be supported in the absence of any evidence of their better quality as compared with that of the independent schools. Otherwise the big school systems will establish their hegemony without meeting the obligations of a franchiser that is, providing necessary support to the franchisees to ensure the delivery of required level of quality education to the youngsters of the nation. They will eat up the small independent schools as the large businesses eat up the small ones leaving no option for the customers.

The study was limited to only ten schools of one franchise system. Further research should be conducted by expanding the scope to more franchise systems with broader area coverage. In addition to the public opinion the research should focus on collecting and comparing empirical data from three types of schools meant for middle and low middle class people that is public schools, independent private schools and franchise private schools. The quality of evidence may be also enriched by multiple sources of data involving other stakeholders and relevant triangulation of data. 


\section{References}

American Institutes for Research and Stanford Research Institute. (2005). National evaluation of the early college high school initiative. Seattle, WA: Bill \& Melinda Gates Foundation

Ali, Z., Ali A., \& Ghani, F. (2010). Expansion of private public schools in Khyber Pakhtunkhwa and policy imperatives: a case study of Peshawar. The Dialogue, 5(4), 390-401.

Barbara, B. (2010). An introduction to franchising, Washington: IFA Educational Foundation.

Barker, R.G., \& Gump, P.V. (1964). Big school, small school: high school size and student behavior. Stanford, CA: Stanford University Press.

Beshel, B. (2010). An introduction to franchising. Washington DC: IFA Educational Foundation.

Bolaji, B.Y., \& Ali, H.B.M. (2013). Preliminary finding of psychometric properties of the existing quality assurance evaluation model (QAEM) for National Universities Commission (NUC) of the Federal Republic of Nigeria. Kuala Lumpur: Global Summit on Education.

BR Research. (2013). Smart schools: smart way of learning. Retrieved from: http://www.brecorder.com/br-research/44:miscellaneous/3205: smart-schools-smart-way-of-(1)earning/

Bunting, I. (1997). Performance indicators for South Africa's education systems. Social Dynamics, 23(1), 139-153.

Chow, L., \& Frazer, L. (2003). Servicing customers directly: mobile franchising arrangements in Australia. European Journal of Marketing, 37(3/4), 594-613.

Chubb, J.E. (2001). The profit motive. The private can be public. Education Next, 1(1).

Dilshad, M., \& Iqbal, H.M. (2010). Quality indicators in English language teachers programmes. Pakistan Journal of Social Sciences (PJSS), 30(2), 401-411.

Dilshad, R.M. (2010). Assessing quality of teacher education: a student perspective. Pakistan Journal of Social Sciences, 30(1), 85-97. 
Elacqua, G., Contreras, D., \& Salazar, F. (2007). The effectiveness of franchises and independent private schools in Chile's national voucher program. Retrieved from: https://openknowledge.worldbank .org/bitstream/handle/10986/2644/490480PUB0emer101Official0Us e0Only1.txt?sequence $=2$

Explore Ville School. (2012). What is franchising. Retrieved from: http://www.explore ville.org.pk/Franchising.php?page_id=74

Feldman, K.A. (1976). The superior college teacher from the students' view. Research in Higher Education, 5(3), 243-288.

Frazer, L., \& Weaven, S. (2004). Franchising Australia 2004 survey. Brisbane: Griffith University.

Frazier, A. (1997). A roadmap for quality transformation in education. Boca Raton, Fla.: St. Lucie Press.

Gill, B., Zimmer, R., Christman, J., \& Blanc, S. (2007). State takeover, school restructuring, private management, and student achievement in Philadelphia. Washington, DC: Rand Corporation.

Govt. of Pakistan. (1959). Report of the Commission on National Education. Pakistan: Karachi;

Govt. of Pakistan. (1979). National education policy. Pakistan: Ministry of Education Islamabad;

Govt. of Pakistan. (1998). National Education Policy (1998-2010). Pakistan: Ministry of Education, Islamabad:

Government of Pakistan. (2016). Pakistan Education Statistics 20142015. Islamabad: Ministry of Federal Education and Professional Training

Gubernick, L., \& Burger, K. (1997). Girls always have trouble with math. Forbes, 159, 120-121.

Gul, S., \& Mehrunnisa. (2008). Temporal expansion of non-government schools in NWFP: a case study of Peshawar. Pakistan: University of Peshawar.

Heaney, J.G., \& Frazer, J. (2005). Education franchising in Australia: can teachers be successful franchisees? ANZMAC Conference: Services Marketing. 
Imran, M. (2008). A comparative study of quality of education in public and private secondary schools of Punjab. Rawalpindi, Pakistan: Arid Agriculture University.

Iqbal, A. (2004). Problems and prospects of higher education in Pakistan, University of Arid Agriculture, Rawalpindi.

Khan, N. (2003). Best TQM practices Guardian's satisfaction index (a case study). Lahore: Pakistan's First National Conference on Quality Assurance in Education, 1-22.

Lee, V.E., \& Loeb, S. (2000). School size in Chicago elementary schools: Effects on teachers' attitudes and students' achievement. American Educational Research Journal, 37(1), 331.

McMeekin, R. (2003). Networks of schools. Education Policy Analysis Archives, 11(16).

Memon, G. R. (2007). Education in Pakistan: The key issues, problems and the new challenges. Journal of Management and Social Sciences, 3(1), 47-55.

Menon, M., Rama, K., Lakshmi, T., \& Bhat, V.D. (2007). Quality indicators for English language teachers. Bangalore: National Assessment and Accreditation Council.

Mirza, M.S. (2003). Quality of primary education in Pakistan. Islamabad: UNESCO.

Perrigot R., \& Warraich M.A. (2016) Franchising in education sector: the Case of Pakistan retrieved from http://www.socialsector franchising.org/news/franchising-in-the-education-sector-the-caseof-pakistan on June 14, 2018

Stufflebeam, D. L. (2003). The CIPP model for evaluation. In D. L. Stufflebeam \& T.

Symonds, W.C. (2000). For profit schools. Business Week, 64-76.

Tam, M. (1999). Quality assurance policies in higher education in Hong Kong. Journal of Higher Education Policy and Management, 21(2), 215-226.

Ullah, M.H. (2005). Comparison of the quality of higher education in public and privatesector institutions in Pakistan. Rawalpindi: University of Arid Agriculture. 
Ullah, M.H., Ajmal, M., \& Rahman, F. (2004). Analysis of quality indicators of higher education in Pakistan. Islamabad: Allama Iqbal Open University.

United Nations Children's Fund (2000). Defining quality in education. New York: UNICEF.

Vos, R. (1996). Educational indicators: what's to be measured? Washington DC: Inter-American Development Bank.

Wasley, P.M., Fine, M., Gladden, N.E., Holland, S.P., King, E., Mosak, E., \& Powell, L.C. (2000). Small schools: great strides. A study of new small schools in Chicago. Retrieved from: http://www.essentialschools.org/cs/resources/view/ ces_res/19.

Whittle, C.I. (2000). Winners of this race are children. Business Week, February 7.

Zaki, W.M., \& Khan, M.S. (1970). Pakistan Education Index. Islamabad: Central Bureau of Education.

Zou, Y., Du, X., \& Rasmussen, P. (2012). Quality of higher education: organizational or educational? A content analysis of Chinese university self-evaluation reports. Quality in Higher Education, 8(2), 169-184.

\section{Citation of this Article:}

Mirza, M. S., \& Manzoor, N. (2018). Quality of education in independent and franchise private secondary schools in Pakistan. Pakistan Journal of Education, 35(2), 137-156.

Received on: July

09, 2017

Revised on: June

14,2018

Accepted on: July

06,2018 